\title{
Frontalis sling surgery: do we really need the Wright needle?
}

\author{
Suspensão ao músculo frontal: realmente \\ precisamos da agulha de Wright?
}

Eduardo Damous Fontenele Feijó ${ }^{1}$, Ana Carla Souza Nery², Roberto Murillo Limongi ${ }^{3}$

\begin{abstract}
Purpose: The aim of this study is to describe a variation in technique of the frontalis sling surgery with silicone rods and its results, using an alternative needle with similar effectiveness to the Wright needle at a reduced cost. Methods: This was a prospective, interventional, noncomparative study of patients with severe ptosis who underwent surgical correction using a simple and modified frontalis sling surgery technique. Patients were included in this study from January 2012 to January 2014. 23 surgeries were performed on 15 patients. The minimum "follow-up" was 12 months. Results: Most patients had congenital ptosis $(86 \%)$ and the average preoperative margin reflex distance 1 (MRD1) was $-1.1 \mathrm{~mm}$ (range -3 to $0 \mathrm{~mm}$ ). 1 week post-operation, this was $2.7 \mathrm{~mm}$ ( 1.8 to $3.8 \mathrm{~mm}$ ), $1.8 \mathrm{~mm}$ after 1 month and $1.7 \mathrm{~mm}$ (1 to $2.5 \mathrm{~mm}$ ) after one year. The satisfaction rate was $80 \%$ (12 patients). Among the dissatisfied patients, one had extrusion and infection with subsequent explantation of the wire, one had asymmetry greater than $2 \mathrm{~mm}$ and one had persistent lagophthalmos and punctate keratitis, with subsequent explantation of silicone. Conclusion: The use of silicone rods with tarsal fixation using an alternative needle was effective in the treatment of severe ptosis with few complication rates, a low rate of dissatisfaction and good stability of the results in the follow-up period.
\end{abstract}

Keywords: Blepharoptosis/surgery; Frontalis sling/surgery; Eyelids/surgery; Ptosis/congenital; Treatment outcome

\section{RESUMO}

Objetivos: O objetivo deste estudo é descrever uma variação da técnica cirúrgica da suspensão ao músculo frontal com fio de silicone e seus resultados, utilizando uma agulha alternativa à agulha de Wright, com a mesma eficácia e melhor razão custo-benefício. Métodos: Foram analisados prospectivamente todos os casos de blefaroptose severa submetidos à correção cirúrgica, utilizando a técnica de suspensão ao músculo frontal modificada, no período de janeiro de 2012 à janeiro de 2014. Foram realizadas 23 cirurgias em 15 pacientes. O "follow-up" mínimo foi de 12 meses. Resultados: A grande maioria dos pacientes apresentavam blefaroptose congênita ( $86 \%)$, a média da distância margem reflexo pré-operatória foi de $-1,1 \mathrm{~mm}(-3$ a $0 \mathrm{~mm})$, no pós-operatório de 1 semana foi de $2,7 \mathrm{~mm}(1,8$ a 3,8 mm), após 1 mês foi de $1,8 \mathrm{~mm}$ e após 1 ano, de $1,7 \mathrm{~mm}(1$ a $2,5 \mathrm{~mm})$. O índice de satisfação foi de $80 \%$ (12 pacientes). Dos 3 pacientes insatisfeitos, 1 teve extrusão e infecção com posterior explante do fio, 1 apresentou assimetria maior que $2 \mathrm{~mm}$ e 1 evoluiu com lagoftalmo persistente e ceratite puntacta, com posterior explante do silicone. Conclusão: $\mathrm{O}$ uso do fio de silicone com fixação tarsal usando uma agulha alternativa, se mostrou eficaz no tratamento da blefaroptose severa, com poucas complicações, baixo índice de insatisfação e boa estabilidade dos resultados no período de seguimento.

Descritores: Blefaroptose/cirurgia; Suspensão ao frontal/cirurgia; Pálpebra/cirurgia; Ptose/congênita; Resultado do tratamento

\footnotetext{
1 Department of Ocular Plastic Surgery, Hospital Oftalmológico de Anápolis, Anápolis, GO, Brazil.

2 Instituto Panamericano da Visão, Goiânia, GO, Brazil.

3 Department of Ocular Plastic Surgery, Universidade Federal de Goiás, Goiânia, GO, Brazil.

The authors declare no conflicts of interest.

Received for publication 09/06/2015 - Accepted for publication 28/11/2015
}

Rev Bras Oftalmol. 2016; 75 (2):89-93 


\section{INTRODUCTION}

$\mathbf{F}$ Irontalis sling surgery is recommended in cases of severe ptosis (greater than 3 millimeters), with a weak or absent function of the upper eyelid levator muscle (UELM) (upper eyelid excursion $<4 \mathrm{~mm})^{(1-10)}$. It is normally found in congenital or acquired myogenic ptosis (myasthenia gravis, mitochondrial myopathy), and in neurogenic (paralysis of cranial nerve III) or post-trauma ptosis. Dransart described the first frontalis suspension in 1880. In 1909, Payr introduced the use of autologous fascia lata, which was later reintroduced by Wright in 1922. In 1966, Tillet and Tillet first described the use of silicone in frontalis suspension to correct ptosis. In the mid-20th Century, authors such as Berk, Jones and Beard systematized surgical techniques and concepts ${ }^{(11)}$.

Various materials have been proposed to make the connection between the upper eyelid (UE) and the frontal muscle, among them, the nylon cord, mersilene, polytetrafluoroethylene (Gore-Tex), a silicone rod, supramid, autologous fascia lata and fascia temporalis transplantations ${ }^{(12-18)}$. The Wright needle is the universal instrument used to guide the materials that connect the frontal muscle to the upper eyelid. Many surgeons find it difficult to handle the needle in this trajectory due to the resistance from tissues in this region, which can result in excessive tissue trauma. The possibility that the needle may break during surgery leading to complications, has been described elsewhere ${ }^{(1)}$.

Our goal is to show the results and stability of frontalis sling surgery in severe ptosis, with the silicone rod attached directly to the upper tarsus, using a simple, effective, safe and low-cost technique.

\section{MethodS}

This is a prospective, interventional, non-comparative, case series study. The protocol of the present study was approved by the Committee on Ethical Research of the Ophthalmologic Hospital of Anapolis (protocol \#023/12). Informed consent was obtained from patients or their guardian before surgery.

A prospective analysis was carried out of all cases of severe ptosis with poor or absent function of UELM operated by the modified frontalis sling surgical technique, using silicone rods, in the Oculoplastic Department of the Ophthalmology Hospital of Anapolis, Brazi, between January 2012 and January 2014.

Minimal post-operative follow-up was one year. Inclusion criteria was severe ptosis (greater than $3 \mathrm{~mm}$ ) and poor UELM function (excursion less than or equal to $4 \mathrm{~mm}$ ). Patients with a weak or absent Bell's phenomenon, or with any clinical contraindications to the procedure, were excluded from the sample.

Based on criteria recommended by Tarbet et al. ${ }^{(19)}$, eyelid height was judged to be "excellent" if MRD1 measured more than $2 \mathrm{~mm}$ and the difference between the two eyelids was equal to or less than $1 \mathrm{~mm}$; "good" if MRD1 ranged from 1 to $2 \mathrm{~mm}$ or if asymmetry was 1.5 to $2 \mathrm{~mm}$ and "poor" if MRD1 measured less than $1 \mathrm{~mm}$ or if asymmetry was greater than $2 \mathrm{~mm}$.

The surgical technique used has been described by Friedenwald-Gyton ${ }^{(5,6,11)}$ with some technical changes. General anesthesia or intravenous sedation plus a local anesthetic with $2 \%$ lidocaine and $0.75 \%$ bupivacaine was used. Skin incision was made with a 15 scalpel blade in the eyelid crease, or when absent, in the upper edge cutaneous projection of the upper tarsal plate. Dissection of the orbicularis muscle and exposing the upper tarsus were done. Two incisions of about $3 \mathrm{~mm}$, were made at the top of the eyebrow, approximately in the medial and lateral projection of the corneal limbus, reaching the periosteum of the frontal bone.

The silicone rod was conducted from tarsal plate to frontalis muscle in the submuscular eyelid plane until it met the eyebrow incisions. The Wright needle was replaced by a surgical needle (1/ $2,0,9 \mathrm{~mm} \times 35 \mathrm{~mm}$ ) (Figure 1), wherein the silicone rod is threaded, leading to the frontal muscle in in the opposite direction of the traditional route (from eyelid to the eyebrow).The silicon rod was fixed in the tarsal plate using three simple 6.0 nylon sutures. The medial silicon tip was externalized in the lateral eyebrow incision, which was pulled and knotted, hyper-correcting the fissure of the eyelid at around 1-2mm (Figure 2). Skin incisions were sutured with 6.0 nylon. Frost suture were performed and patients were instructed to use cold compresses for three days and lubrificants for 30 days. The application of antibiotic ointment on incisions and eyes prior sleeping were prescribed for a 15 day period. Post-operative examination was carried out 24 hours, 1 week, 1 month, 6 months and 1 year post-surgery.

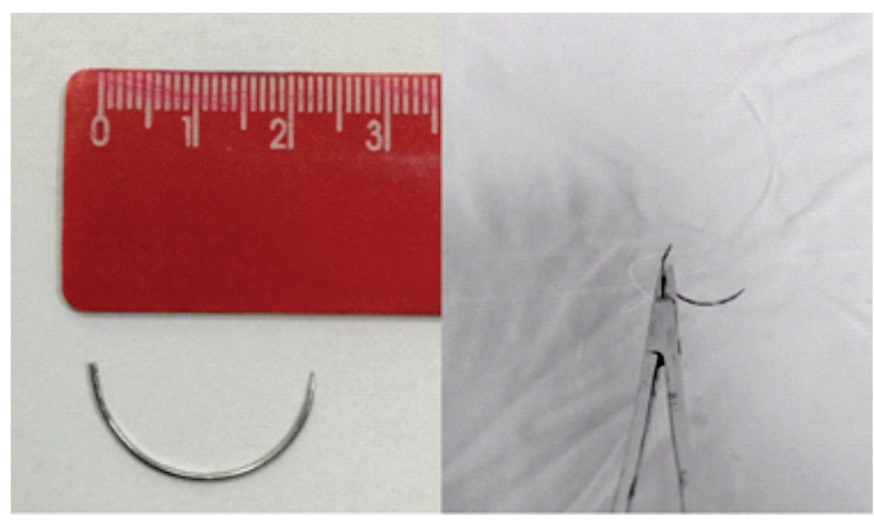

Figure 1: Surgical needle with silicone rod threaded through
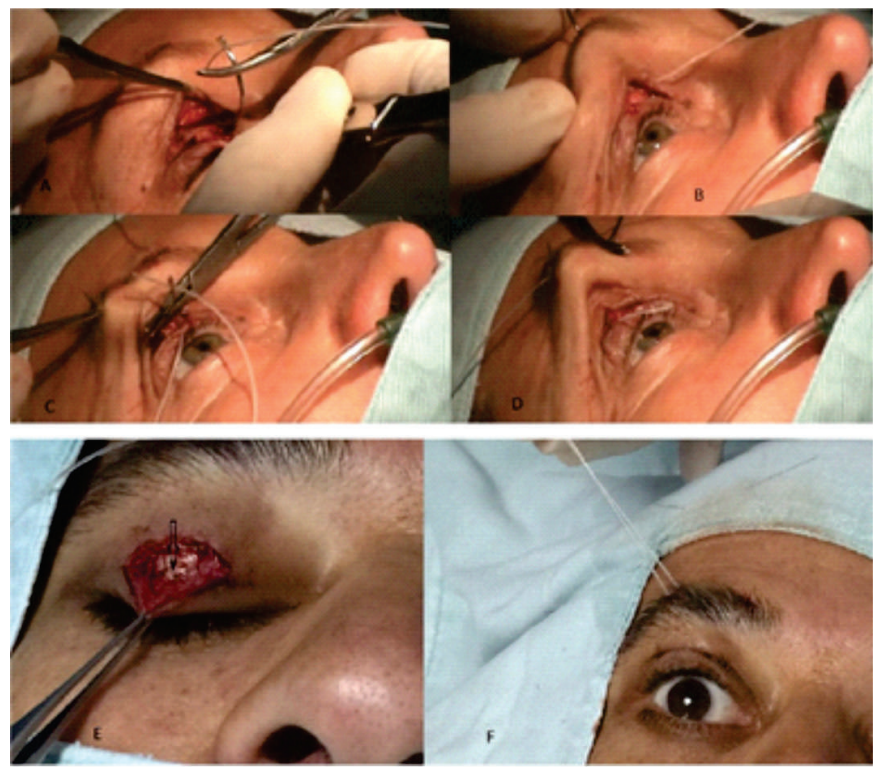

Figure 2: A, B, C and D: Exposure of upper tarsus and conduction of the silicone rod from tarsal plate to frontalis muscle. D and F: Silicone fixation in a loop on the upper tarsal in three simple sutures (arrow) and intraoperative adjustment of eyelid fissure. 


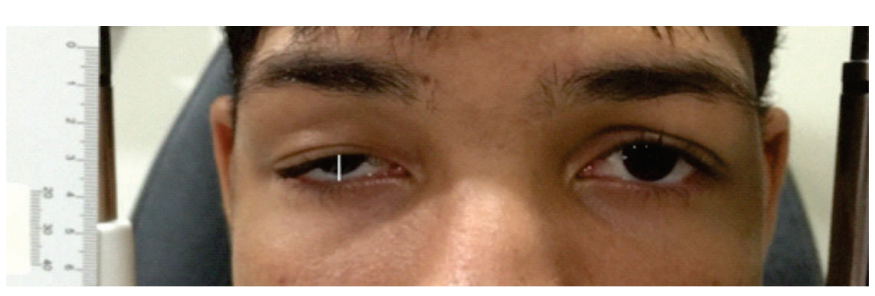

Figure 3: Millimeter ruler attached to the slit lamp and digital image processing.

Digital images were taken using a Sony W250 Cybershot camera, at a distance of about 40 centimeters, with the patient seated, positioned at the slit lamp, with a ruler fixed to the lamp support (Figure 3 ). The digital processing of the images and the measurements of the eyelid fissure pre- and post-operative, were carried out using Image J software (National Institutes of Health, Maryland, USA). This program performs the proposed measure by calculating the number of pixels in the image. A known scale is converted into pixels and from there any measurements can be performed, taking as a reference a known measurement in the digital photograph in question.

The student " $\mathrm{t}$ " test was used to compare averages.

\section{ResUlts}

23 eyelids belonging to 15 patients were included in the study. Nine $(60 \%)$ of the patients were male, the mean age was 27.8 (6 to 65$)$, eight patients ( $56 \%$ ) had both eyes corrected, four patients $(26.6 \%)$ had left eye ptosis and three $(20.6 \%)$ had the right eye affected.

The vast majority of patients had congenital ptosis $(86 \%$ 13 patients), while the two others showed oculomotor nerve palsy (one patient) and myasthenia gravis (one patient). One case of congenital ptosis included blepharofimosis syndrome.

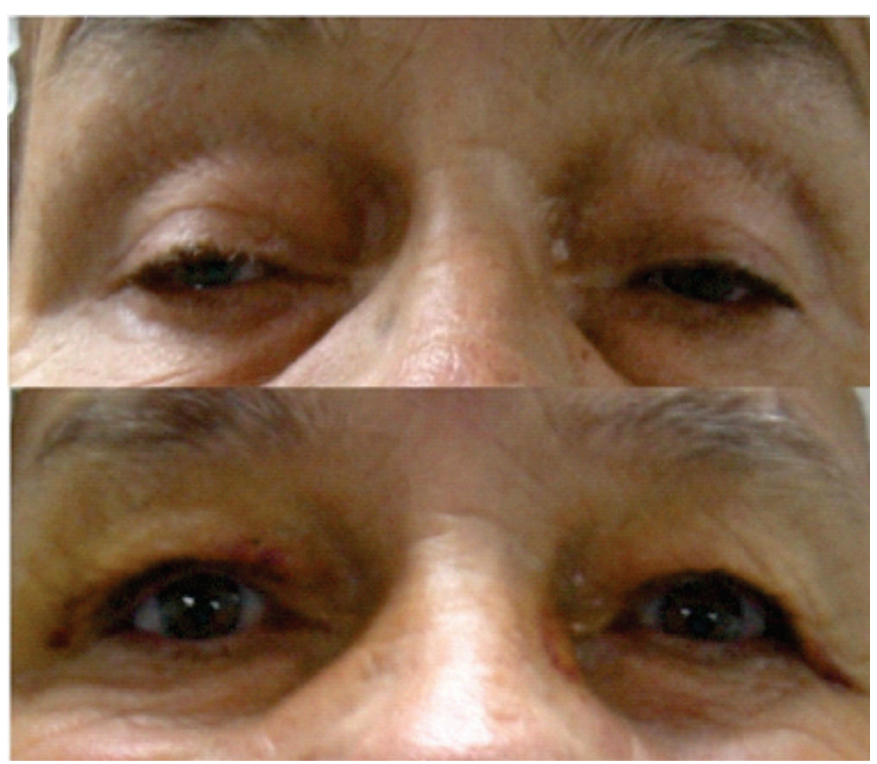

Figure 4: Patient with severe ptosis: pre and postoperative appearance.

Measurement of the average preoperative margin reflex distance 1 (MRD1) was of $-1.1 \mathrm{~mm} \pm 0.59 \mathrm{~mm}(-3$ to $0 \mathrm{~mm})$, preoperative eyelid excursion average was of $2.2 \mathrm{~mm} \pm 0.84 \mathrm{~mm}$ ( $1-4 \mathrm{~mm})$. One week after the procedure, the MRD1 was $2.7 \mathrm{~mm}$ $\pm 0.92 \mathrm{~mm}(1.8-3.8 \mathrm{~mm})$ and one month after procedure was $1.8 \mathrm{~mm} \pm 1.09 \mathrm{~mm}(1.1-2.5 \mathrm{~mm})$. After six months of postoperative, the mean extent of the eyelid fissure was $1.7 \mathrm{~mm} \pm 0.90 \mathrm{~mm}(1-2.5$ $\mathrm{mm}$ ), a result that remained stable after one year (Figure 4). The average correction of ptosis by this technique after one year was of $2.8 \mathrm{~mm}$ ( $2 \mathrm{~mm}$ to $3.6 \mathrm{~mm})$. There was a mean eyelid drop of $1 \mathrm{~mm}$ from the one week after surgery to one year follow up (MRD1 $2.7 \mathrm{~mm}$ in 1 week to $1.7 \mathrm{~mm}$ in 1 year). The statistics of the outcomes were confirmed using the student " $t$ " test $(p<0,001)$.

Lagophthalmos occurred in $60 \%$ of patients (12 cases), although only one patient had severe lagophthalmos with persistent corneal keratitis. Undesirable asymmetry occurred in two patients $(13.3 \%)$. The aesthetic satisfaction rate of the patients was $80 \%$ (12 patients), while for three patients the result was unsatisfactory: one had severe lagophthalmos, one had an extrusion with infection and one had an asymmetry greater than $2 \mathrm{~mm}$.

Considering the criteria recommended by Tarbet et $\mathrm{al}^{7}$, the results for three patients were considered "excellent", "good" for nine patients and "poor" for three.

\section{DisCUSSION}

Blepharoptosis is a condition that can cause many problems of a psychological and visual nature. Correct diagnosis and treatment can prevent possible amblyopia through visual deprivation in patients with severe ptosis, sometimes occluding the visual axis, thus preventing correct vision development and causing amblyopia ${ }^{(17-22)}$.

Frontalis sling surgery, as described by $\operatorname{Fox}^{(1-7,13)}$, can be used for the surgery, along with various materials. Silicone rods produce little tissue reaction and are elastic, thus allowing the patient's eyes to close properly through the contraction of the orbicularis muscle. Another advantage of the silicone rod is the fact that we do not need to use another surgical site on the patient, as in the withdrawal of fascia lata or fascia temporalis, which would improve the mobility ${ }^{(12,14,15)}$. However, by being elastic, it may have a tendency to slack a little during post-surgery, which may mean the result is less stable in the long term ${ }^{(12,16,23-26)}$

The simple passage of the silicone rod in the epitarsal plan does not guarantee stability of the material at that location, as superior migration may occur, resulting in a recurrence of ptosis and less stable results. We prefer to make an incision in the eyelid crease and expose the upper tarsus and fix the silicon rod with three simple sutures using 6.0 mononylon. This is non-absorbable so causes less adverse reactions and avoids the appearance of eyelid granulomas. This fact was confirmed in this paper, given that we had no cases with this complication. This direct attachment to the tarsus reinforces the eyelid crease, leaving a more aesthetic result $(7,17,18)$. Yagci et al. ${ }^{(18)}$ compared two groups of patients with severe ptosis and poor UELM function. One group underwent frontalis sling surgery following the classic technique described by Fox, while the other group underwent surgery with the silicone rod sutured to the tarsus, keeping two stitches in the eyebrow and one in front. The group with the direct attachment to the tarsus achieved good aesthetic results in $76.6 \%$ of cases, while the other group achieved the same results in $46 \%$ of cases.

Another variation of the Fox technique, modified by Friedenwald-Gyton $^{(5,6,11)}$ was the performance of only two incisions near the top edge of the eyebrow (also called simple rhomboid technique), one medial and another lateral, avoiding 
the upper incision, as we find it more aesthetic. The knotting of the silicon rod was done in the eyebrow's lateral incision. As the tail of the eyebrow generally has a higher mobility compared to its medial part, it is supposed that this could contribute to the improvement of the functional outcome. In the passage of the silicone rod, we did not use the Wright needle, but used a curved eyed needle instead. Therefore, the depth of the passage of the rod can be better controlled, avoiding eye injuries. Besides, as the needle has a cutting and piercing tip, inserting it is easier than the conventional way.

This study presented a ptosis correction index of $2.8 \mathrm{~mm}$ after one year follow up. There was an average eyelid drop of 1 $\mathrm{mm}$ between one week and one year post surgery. The probable causes for this include the material elasticity, which can slack a little over time and the lack of tissue reaction with consequent fibrosis, which could leave a more stable result ${ }^{(26-28)}$. Lee et al ${ }^{(20)}$ compared outcomes of patients operated with fascia lata and silicone rods and found better aesthetic results and a lower rate of complications with the silicone rod. Ben Simon et $\mathrm{al}^{(29)}$ also compared outcomes of patients operated with nylon, silicone rods, fascia lata and polytetrafluorethylene and revealed more recurrence rate and complications in the silicone group. Many studies have shown that the results are highly variable for the rates of recurrence and complications. Still, prospective randomized trials are required to confirm the superiority of silicone over the fascia lata and to compare silicone with other materials. Studies have also shown that nylon, Mersilene and polytetrafluorethylene (PTFE or "Gore-tex") also have good acceptance, but show varying rates of extrusion, infection, and granuloma formation ${ }^{(11)}$.

In our study, only one patient had to undergo silicone rod explantation for severe lagophthalmos with persistent keratitis and another patient had the rod explanted through extrusion with subsequent infection and pre-septal cellulitis. For most, the situation was resolved up to the first month after surgery, using eye drops ${ }^{(17,28,29,30)}$.

The satisfaction rate with the functional and aesthetic result was excellent ( $80 \%$ - 12 patients). Although some patients have asymmetries of $1 \mathrm{~mm}$, it was considered negligible when evaluating themselves. Three patients (20\%) were dissatisfied with the result, two had an asymmetry greater than two $\mathrm{mm}$ and one of them had a wire extrusion through a temporal incision to the eyebrow, with subsequent infection and pre-septal cellulitis and wire explant. One of them had severe and persistent lagophthalmos, with corneal keratitis and asymmetry, which led us to explant the wire. This patient had paralysis of the oculomotor nerve, which may have contributed to surgery failure. These facts are consistent with Zulfiquar et al. ${ }^{(17)}$, that has a surgical success rate of $94.3 \%$ using the Fox technique with silicone rod, while no patient had exposure keratopathy. Fogagnolo et al ${ }^{(19)}$ performed 22 frontal suspensions with silicone rods in pediatric patients, with an average correction rate of $2.3 \mathrm{~mm}$ in a one-year followup. The eyelid dropped by an average of $0.8 \mathrm{~mm}$ from the first week after surgery to the first year. This data is consistent with that found in our study.

Recently in the USA, some oculoplastic surgeons have used a new instrument called Aurosling ${ }^{\mathrm{TM}}$ (Aurolab, Tamil Nadu, India). This consists of two straight needles connected by their ends with silicone rods, and represents an alternative to the Wright needle. This instrument is not available in Brazil, since it has not been allowed by local sanitary agencies, and importing it will increase the cost of surgery. Our alternative is more simple, low cost and effective.

Although our case study had a small sample, we can say that this technical modification demonstrated good functional and aesthetic results, but a longer follow-up period and a larger sample would be necessary to draw a more grounded conclusion.

\section{Conclusion}

In conclusion, the correction of severe ptosis with poor or absent levator function through the modified suspension technique with surgical needle and silicone rod was effective in the functional outcome, and remained aesthetically stable within one year of follow-up.

\section{REFERENCES}

1. Betharia SM. Frontalis siling: a simple modified technique. Br J Ophthalmol. 1985, 69(6): 443-5.

2. Kanski JJ, Bowling B. Clinical Ophthalmology. São Paulo: Elsevier; 2011.

3. Nerad JA Techniques in ophthalmic plastic surgery. Cincinnati: Saunders; 2010

4. Putterman, AM. Oculoplástica aesthetic surgery. Rio de Janeiro: Elsevier; 2009.

5. Matayoshi, S. Manual de cirurgia plástica ocular. São Paulo: Rocca; 2004.

6. Soares EJ, Figueiredo AR, Souza GL, HC Almeida, Oliveira LR, Magellan, MM, Portellinha WM. Blepharoptosis. In: Soares EJ, Moura IN, Gonçalves JO, editors. Ocular plastic surgery. São Paulo: Rocca; 1997.p.77-152.

7. Sant'Anna AE, Genta CB, Portelinha W. Use of PTFE (GoreTex) for treatment of severe ptosis. Arch Ophthalmol. 1994; 57(2):84-6.

8. Hornblass A, Kass LG, Ziffer AJ. Amblyopia in congenital ptosis. Ophthalmic Surg. 1995; 26(4):334-7.

9. Stärk N, Zubcov AA, Kast E, Gutermuth D. [Amblyopia, refractive errors and strabismus in congenital ptosis]. Ophthalmologe. 1996; 93(4):345-50. German.

10. Fiergang DL, Wright KW, Foster JA. Unilateral or asymmetric congenital ptosis, head posturing, and amblyopia. J Pediatr Ophthalmol Strabismus. 1999; 36(2):74-7.

11. Matayoshi S, Pereira IC, Rossato LA. Surgical treatment of congenital ptosis. Rev Bras Oftalmol. 2014; 73 (4):202-9.

12. Wasserman BN, Sprunger DT, Helveston MS. Comparison of materials used in frontalis suspension. Arch Ophthlamol. 2001; 119(5):687-91.

13. Fox SA. Ophthalmic plastic surgery. 3rd ed. New York: Grune \& Stratton; 1963.

14. Broughton WL, Matthews JG 2nd, DJ Harris Jr. Congenital ptosis. Results of treatment using lyophilized fascia lata for frontalis suspensions. Ophtalmology. 1982; 89(11):1261-6.

15. Liu D. blepharoptosis correction with frontalis suspension using the sling supramid: duration of effect. Am J Ophthalmol. 1999; 128(6):772-3.

16. Bernardini FP, of Conciliis C, Devoto MH. Frontalis suspension sling using the silicone rod in Patients Affected by myogenic blepharoptosis. Orbit. 2002; 21(3):195-8.

17. Ali Z, Kazmi HS, bin Saleem MK, Shah AA. Silicon tube frontalis suspension in simple congenital blepharoptosis. J Ayub Med Coll Abbottabad. 2011; 23(4):30-3.

18. Yagci, Egrilmez S. Comparison of cosmetic results in frontalis sling operations: the eyelid crease incision versus the supralash stab incision. J Pediatr Ophthalmol Strabismus 2003; 40(4):213-6. 
19. Fogagnolo P, Serafino M, Nucci P. Stability of silicone band frontalis for the treatment of severe unilateral upper eyelid ptosis in infants. Eur J Ophthalmol. 2008; 18 (5):723-7.

20. Lee MJ, Oh JY, Choung HK, Kim NJ, Sung MS, Khwarg SI. Frontalis sling operation using silicone rod compared with preserved fascia lata for congenital ptosis a three-year follow-up study. Ophthalmology. 2009; 116(1):123-9.

21. Steinkogler FJ, Kuchar A, Huber And Arocker-Mettinger E. GoreTex soft-tissue patch frontalis suspension technique in ptosis and blepharophimosisptosis syndrome congenital. Plast Reconstr Surg. 1993; 92(6):1057-60.

22. Jeong S, Ma YR, Park YG. Histopathological study of frontalis suspension Materials: Jpn J Ophthalmol. 2000; 44(2):171-4.

23. Small RG, Sabates NR, Burrows D. The measurement and definition of ptosis. Ophthal Plast Reconstr Surg. 1989; 5(3):171-5.

24. Finsterer J. Ptosis: causes, presentation, and management. Aesthetic Plast Surg. 2003; 27(3):193-204.

25. Beard C. Ptosis. 3rd ed. St Louis: CV Mosby; 1981. p.84-174.

26. Grebos SP, Almeida T, Barbosa KH, Buquera MA, Moreira AT. Mitochondrial myopathy: report of two cases. Arch Ophthalmol. 2005; 68(5) 675-8.
27. Wong VA, Beckingsale PS, Oley CA, TJ Sullivan. Management of myogenic ptosis. Ophtalmology. 2002; 109(5):1023-31.

28. Lane CM, Collin JR. Treatment of ptosis in chronic progressive external ophthalmoplegia. Br J Ophthalmol. 1987;71(4):290-4.

29. Ben Simon GJ, Macedo AA, Schwarcz RM, Wang DY, McCann JD, Goldberg RA. Frontalis suspension for upper eyelid ptosis: evaluation of different surgical designs and suture material. Am J Ophthalmol. 2005;140(5):877-85.

30. Fan J. Frontalis suspension technique with a temporal-fasciaecomplex sheet for repairing blepharoptosis. Aesthetic Plast Surg. 2001;25(3):147-51.

\section{Corresponding author:}

Eduardo Damous Fontenele Feijó

Endereço: Av. Faiad Hannah, 235, Cidade Jardim, Anápolis, GO, Brazil. Zip code: 75080-410

E-mail: eduardodff@yahoo.com.br 